\title{
Estimation of bioenergy potential for local biomass in the United Arab Emirates
}

\author{
Muhammad Tahir Ashraf, Chuanji Fang, Tomasz Bochenski, Iwona Cybulska, Ayah Alassali, \\ Akinleye Sowunmi, Rashed Farzanah, Grzegorz Przemyslaw Brudecki, Tanmay Chaturvedi, Sabeera Haris, \\ Jens Ejbye Schmidt, Mette Hedegaard Thomsen*
}

Institute Center for Energy - iEnergy, Masdar Institute of Science and Technology, PO Box 54224, Abu Dhabi, United Arab Emirates

\section{A B S T R A C T}

\begin{abstract}
The wide range of biomass spectrum in the United Arab Emirates (UAE) can be used for bioenergy production. The objective of this study is to highlight this potential by analyzing the bioethanol and biomethane potential of biomasses found in the UAE. Eighteen different biomass species and their fractions, including lignocellulose (date palm, Moringa peregrina, mangroves, and garden trimmings), halophytes (Salicornia sinus-persica and Salicornia bigelovii), seagrass (Halodule uninervis, Halophila ovalis, and Halophila stipulacea), macroalgae (Ulva Sp., Padina boergesenii, and Colppmenia sinuosa), and wastes (municipal and manures), were analyzed for bioenergy potential. Bioethanol production ranged from 55 to $359 \mathrm{~kg}$ ethanol/ton and biomethane production from 72 to $288 \mathrm{~L} \mathrm{CH}_{4} / \mathrm{kg}$ from biomass of species selected here. Results indicate that lignocellulosic biomass furnishes higher bioethanol potential, whereas macroalgae $(P$. boergesenii) has the least bioethanol potential and washed $S$. bigelovii, lignocellulosic garden trimmings, and camel manure are best suited for biomethane production. Significant variations in bioethanol and biomethane potential have also been noticed between different biomass fractions.
\end{abstract}

Keywords: Bioenergy potential; Bioethanol; Biomass; Biomethane; Waste to energy

\section{INTRODUCTION}

The rapidly increasing global population, urbanization and industrialization have resulted in growing energy demands and a consequent increase in greenhouse gas (GHG) emissions. In $2010 \mathrm{GHG}$ emissions reached approximately $49 \pm 4.5 \mathrm{GtCO}_{2 \mathrm{eq}} / \mathrm{yr}$, of which $78 \%$ was $\mathrm{CO}_{2}$. This is the highest value in human history (IPCC, 2014). The rising GHG emissions are coupled with increasing demand of energy. In 2012, world energy consumption was estimated to be ca. $557 \mathrm{EJ} / \mathrm{yr}$, with $10 \%$ originating from biofuels and waste (IEA, 2014). By 2050 the world's energy demand is expected to rise to $600-1000 \mathrm{EJ} / \mathrm{yr}$; sustainable biomass utilization can provide 200-500 EJ/yr (IEA Bioenergy, 2009). A recent analysis of current polices and future development trends predicted bioenergy share of 40-110 $\mathrm{EJ} / \mathrm{yr}$ in 2050 (Searle and Malins, 2015), which is lower than the potential estimated by IEA. In the future energy market, to meet the GHG mitigation challenge, it is crucial to increase the contribution of biofuels. Between 2011 and 2035, biofuels share in the road-transportation fuel is projected to rise from 3\% to $8 \%$ worldwide (IEA, 2013). Moreover, as biofuels like cellulosic ethanol and biogas are still at a development or pilot stage (IEA, 2013), it is expected that they have a larger potential to increase biofuel supply and reduce the sustainability concerns of biofuels.

Some countries, such as the USA, Europe, and China, have initiated research and development programs in biofuels, a sustainable and renewable energy resource that can provide liquid transportation fuels. The USA has targeted a production of 36 billion gallons of biofuel by 2022 of which $58 \%$ may be produced from second generation biofuels (EISA, 2007). The European Council's (March, 2007), target for the European Union is that $10 \%$ of all diesel and gasoline transport fuel may be produced from sustainable second generation biofuels (CEU, 2007). China's annual production target of bioethanol, as outlined in "The Medium and Long-Term Development Program for Renewable Energy" of 2007, is 10 million tons by 2020 (Qiu et al., 2012). The UAE has committed to obtaining $7 \%$ of its installed power from renewable sources by

\footnotetext{
*Corresponding author:

Mette Hedegaard Thomsen, Institute Center for Energy - iEnergy, Masdar Institute of Science and Technology, PO Box 54224, Abu Dhabi, United Arab Emirates, E-mail: mthomsen@masdar.ac.ae 
2020 (Emirates News Agency, 2009). However, concerns about use of arable land and cost of food commodities are motivating factors for supporting the production of lignocellulosic biofuels. Replacing biofuels made from commodities that can also be used to produce food with cellulosic biofuels, would likely lead to lower food prices. Given the wide availability of potential lignocellulosic feedstock, it is possible to envision a future in which gasoline and diesel are partially replaced by a second generation biofuels. Searle and Malins (2015) predicted a potential biofuel production of 10-20 EJ/yr by 2050 .

Several studies have estimated a bioenergy potential for countries rich in agricultural and forest residues, like USA, Britain, South Africa, India, China, and Pakistan (Blanchard et al., 2015; Butt et al., 2013; Hiloidhari et al., 2014; Ji, 2015; Tan et al., 2012). Utilization of single biomass for the production of biofuels has been demonstrated on a large scale with large capacities coming online. For example, DuPont's $\$ 225$ million cellulosic ethanol plant in Nevda, Iowa opened on October 30, 2015. It is the largest cellulosic ethanol facility in the world and is expected to produce 30 million gallons of cellulosic ethanol per year from 375,000 dry tons of corn stover (DuPont, 2015a). The process uses mild ammonia pre-treatment which is suitable for corn stover and Zymomonas mobilis fermentation; both these technologies were optimized with collaboration between DuPont and NREL (US DOE, 2015). Quad County Corn Processors are producing 4 million gallons of cellulosic ethanol from corn grain leftovers using DuPont OPTIMASH ${ }^{\mathrm{TM}}$ enzyme (DuPont, 2015b). Inbicon and Dong Energy demonstration plant in Kalundborg, Denmark produces cellulosic ethanol from wheat straw. It has been in operation since 2009 and operates at 4.4 tons per hour capacity and produces 5.4 million gallons of ethanol and 14,330 tons of lignin pellets annually (Inbicon, 2015). Maabjerg Energy Contre (MEC) has announced the largest cellulosic ethanol facility in Maabjerg, Denmark starting production in 2018. The plant will produce 80 million gallons of ethanol, 50 million cubic feet of biogas, and electricity for 25,000 households from 330,700 tons of wheat straw (MEC, 2015).

Envisioning a biorefinery in the UAE begins with the challenge of securing a sustainable supply of biomass feedstock. The UAE has a different biomass spectrum due to its geographical characteristics, as most of its land is arid with desert plants. The first step is to identify and analyze the indigenous biomass resources for bioenergy potential. A brief introduction of some of the abundant biomass species is given below.

Marine habitats have potential for bioenergy production, using seawater for crops production along the coastal deserts may eventually provide 130 million ha of new cropland (Lu et al., 2010). The UAE's 650 kilometers of coastline is abundant in sea grasses and macroalgae. In addition to marine habitats, land near coastlines is suitable for salt tolerant halophytes crops. These crops do not require fresh-water and fertile soil (Rozema and Flowers, 2008) and have been planted in the UAE as integrated seawater agriculture/aquaculture to produce biofuels (ICBA, 2011). In this study halophytes Salicornia bigelovii, native Salicornia sinus-persica, and seagrasses Halodule uninervis, Halophila ovalis, and Halophila stipulacea which occur in the Arabian Gulf (EAD, 2007) are analyzed for bioenergy potential. Local macroalgae specie analyzed are Ulva Sp., Padina boergesenii, and Colppmenia sinuosa.

Date palm (Phoenix dactylifera L.) is the most important agricultural crop in Arab countries, with the UAE having the largest number of this specie (considering a referential of a single country, about 40 million date palm trees and a minimum of 200 cultivars) (El-Juhany, 2010). Each date palm tree produces $10-30$ dried leaves annually and an average of 2-3 kilograms of naturally dried leaf (including leaflets and rachis) (Mallaki and Fatehi, 2014). Hence, each date palm tree is estimated to yield $50 \mathrm{~kg}$ leaf residues annually. Therefore, the annual yield of lignocellulosic feedstock from date palm leaf residues might reach over 2 million tons. Besides, the UAE produces 1.79 million tons of agricultural waste (excluding date palm) being only $10 \%$ is recycled (National Bureau of Statistics, 2013a). Accordingly, there is a strong potential for bioenergy production using these wastes. Further sources of lignocellulosic are Bermuda grass, Jasmine hedges, Avicennia marina, and Moringa peregrine. Bermuda grass and Jasmine hedges are commonly grown in landscapes, gardens, and parks and produce a regular stream of agriculture waste due to trimmings. M. peregrina is a native and naturalized plant in the UAE (Shahin et al., 2014) and is also suitable for landscaping." A. marina (commonly known as grey mangrove), prevails in the UAE coastal area (Shriadah, 1999).

UAE has a daily per capita municipal solid waste of $1.9 \mathrm{~kg} /$ day, which is one of the highest in the world (National Bureau of Statistics, 2013a, 2011). In the UAE, 5.89 million tons of municipal solid waste is produced, being $20 \%$ recycled while the remaining fraction is sent for landfill. In this context, the organic fraction of the municipal solid waste (OFMSW) can be used for biofuel production. Livestock in the UAE is one of the most important agricultural activities, livestock farming being expected to increase the output in coming years and leading to higher production of animal dung (National Bureau of Statistics, 2013b). Accordingly, it is important to provide possible options to utilize dung, otherwise it becomes a 
nuisance. Bioenergy derived from camel, sheep, goat and cattle manure is included in the study.

In this study the local biomass of UAE (halophytes, sea grasses, macroalgae, lignocellulosics, and municipal and animal waste) is assessed, at a chemical level, to evaluate its potential for bioenergy production.

\section{MATERIALS AND METHODS}

\section{Raw material}

S. bigelovii was cultivated by International Center for Biosaline Agriculture (ICBA), using seeds provided by Masdar Institute for the ISEAS project (ICBA, 2011). Native strains of S. sinus-persica were collected from Umm Al Quwain, UAE shores. The GPS coordinates and time of sample collected are given in Table 1. The collected samples were washed with tap water to remove salt deposits on the surface of biomass. S. sinus-persica samples were pressed to obtain the juice and pulp fraction. Juice was stored at $-18^{\circ} \mathrm{C}$ until use. Pulp or fiber fractions of both raw and washed samples were dried, finely crushed and stored in air tight bags until use.

Seagrasses (H. Uninervis, H. Stipulacea, and H. Ovalis) and macroalgae (Ulva Sp., P. boergesenii, and C. sinuosa) samples were collected from Abu Dhabi shores. The fractions of date palm residues (leaflets, rachis, fruit stalks and trunks) were collected (location) in Abu Dhabi, UAE. Bermuda grass and Jasmine hedges samples were collected from a roadside landscape of Zayed Sports City area in Abu Dhabi, UAE. M. peregrine samples were collected in Sharjah. A. marina was collected from Eastern mangroves area in Abu Dhabi. The samples were air dried and crushed to obtain particle sizes lower than $2 \mathrm{~mm}$ and then stored in air tight bags until further use.

A model organic municipal solid waste (mOFMSW), as previously defined in Nwobi et al. (2014), was prepared

Table 1: Samples collection GPS coordinates and dates

\begin{tabular}{|c|c|c|}
\hline Sample & Coordinates & Time \\
\hline S. sinus-persica & 2550'59.94”'N 5561'53.79"'E & February 2013 \\
\hline H. Stipulacea & $24^{\circ} 27^{\prime} 43.77^{\prime} \mathrm{N} 54^{\circ} 35^{\prime} 34.10^{\prime} \mathrm{E}$ & March 2013 \\
\hline $\begin{array}{l}\text { H. Uninervis, } \\
\text { H. Ovalis }\end{array}$ & $24^{\circ} 27^{\prime} 36.70^{\prime \prime} \mathrm{N} 54^{\circ} 32^{\prime} 13.23^{\prime \prime} \mathrm{E}$ & March 2013 \\
\hline Ulva Sp. & $24^{\circ} 45^{\prime} 52.85^{\prime \prime} \mathrm{N}, 54^{\circ} 40^{\prime} 51.02^{\prime \prime} \mathrm{E}$ & November 2012 \\
\hline P. boergesenii & $24^{\circ} 27^{\prime} 36.70^{\prime \prime} \mathrm{N}, 54^{\circ} 32^{\prime} 13.23^{\prime \prime} \mathrm{E}$ & March 2013 \\
\hline C. sinuosa & $24^{\circ} 63^{\prime} 47.07^{\prime \prime} \mathrm{N}, 54^{\circ} 52^{\prime} 19.69^{\prime \prime} \mathrm{E}$ & April 2013 \\
\hline Date palm & $24^{\circ} 22^{\prime} 58.1^{\prime \prime} \mathrm{N} 54^{\circ} 42^{\prime} 53.7^{\prime \prime} \mathrm{E}$ & March 2014 \\
\hline $\begin{array}{l}\text { Bermuda grass, } \\
\text { Jasmine Hedges }\end{array}$ & $24^{\circ} 41^{\prime} 96.63^{\prime \prime} \mathrm{N} 54^{\circ} 45^{\prime} 87.71^{\prime \prime} \mathrm{E}$ & March 2014 \\
\hline M. peregrine & $25^{\circ} 28^{\prime} 05.72^{\prime \prime} \mathrm{N} 55^{\circ} 69^{\prime} 73.16^{\prime \prime} \mathrm{E}$ & November 2013 \\
\hline A. marina & $24^{\circ} 44^{\prime} 74.69^{\prime \prime} \mathrm{N} 54^{\circ} 43^{\prime} 04.96^{\prime \prime} \mathrm{E}$ & November 2013 \\
\hline Animal manure & $24^{\circ} 52^{\prime} 06.68^{\prime \prime} \mathrm{N} 54^{\circ} 37^{\prime} 57.07^{\prime \prime} \mathrm{E}$ & November 2013 \\
\hline
\end{tabular}

Emir. J. Food Agric • Vol $28 \bullet$ Issue $2 \bullet 2016$ artificially by mixing following components: $11 \%$ rice, $5 \%$ pasta, $7 \%$ potatoes, $2 \%$ corn, $4 \%$ bread, $1 \%$ pineapple, $1 \%$ apple, $1 \%$ carrot, $2 \%$ cucumber, $3 \%$ lemon, $1 \%$ pawpaw, $6 \%$ tomatoes, $3 \%$ pickles, $6 \%$ meat, $14 \%$ fish, $6 \%$ dairy, $2 \%$ cabbage, $2 \%$ lettuce, $2 \%$ okra, $2 \%$ eggplant, $2 \%$ cauliflower, $2 \%$ broccoli, $13 \%$ vegetable oil, $1 \%$ newspaper, $0.6 \%$ cardboard, and $0.4 \%$ paper. Model waste mOFMSW was kept at $4{ }^{\circ} \mathrm{C}$ until use. Animal manure (cattle, camel, sheep and goat) were collected fresh from Al Mina Automated Slaughter House in Abu Dhabi and was stored at $4^{\circ} \mathrm{C}$ until use.

\section{Composition analysis}

To determine total solid (dry matter DM) and ash contents, biomass were dried at 105 and $575^{\circ} \mathrm{C}$ overnight, respectively (Sluiter et al., 2008a, 2008b). The compositional analysis followed (Sluiter et al. 2008, 2011). Non-structural components were measured using water and ethanol extraction, using a Soxhlet apparatus. About $5 \mathrm{~g}$ of biomass was loaded into a cellulose thimble and subjected to 10 hours of extraction with $200 \mathrm{~g}$ of water (with 3-4 siphon cycles per hour) and 10 hours extraction with $200 \mathrm{~g}$ of ethanol (5-6 siphon cycles per hour). Siphon cycles were maintained by boiling off water/ethanol using heating mantle (Electrothermal EM 0500) and while maintaining condenser temperature at $15^{\circ} \mathrm{C}$ by circulating refrigerated water from WiseCircu ${ }^{\circledR}$ (WCR-P8) water bath. Extractivesfree biomass was dried in an oven at $105^{\circ} \mathrm{C}$ overnight. Total extractives and non-volatile water/ethanol extractives were calculated according to Eq. 1 and 2, respectively.

Total extractives $\left(\frac{g}{100 g T S}\right)=\frac{D M(g)-W_{\text {dried extracted biomass }(g)}}{D M(g)} \times 100$

Non-volatile extractives $\left(\frac{g}{100 g T S}\right)=\frac{W_{\text {dried extrats water or ethanol }(g)}}{D M(g)} \times 100$

Analysis of structural carbohydrates and Klason (acid insoluble) lignin was carried out applying a strong acid hydrolysis. About $0.3 \mathrm{~g}$ of dried extractive free sample and $3 \mathrm{~mL}$ of $72 \%$ sulfuric acid was added in four $120 \mathrm{~mL}$ pressure tubes. Tubes were incubated in a water batch at $30{ }^{\circ} \mathrm{C}$ for $1 \mathrm{~h}$, then $84 \mathrm{~mL}$ of Millipore water was added. The tubes were autoclaved for $60 \pm 5$ minutes at $121^{\circ} \mathrm{C}$. Samples were then filtered and the filtrate was analyzed in high performance liquid chromatography (Agilent 1260 Infinity Bio-inert Binary LC). The Hi Plex-H column (Agilent) and refractive index detector (RID) were used to determine the concentrations of glucose, xylose and arabinose, at $65{ }^{\circ} \mathrm{C}$, using $0.005 \mathrm{M} \mathrm{H}_{2} \mathrm{SO}_{4}$, as the mobile phase (eluent), with a flow rate of $0.6 \mathrm{~mL} / \mathrm{min}$. The 
residues from filtration were washed, dried at $105 \pm 3^{\circ} \mathrm{C}$ and baked at $450 \pm 5^{\circ} \mathrm{C}$ for acid insoluble lignin (Klason lignin) measurement. Eq. 3-5 summarize the calculations used for structural carbohydrates and Klason lignin.

Suagars $_{\text {extratss free }}\left(\frac{g}{100 g T S}\right)=\frac{C_{\text {anhydro }}\left(\frac{g}{L}\right) \times V_{\text {bydrobsate }(L)}}{D M_{\text {extracts free }}(g)} \times 100$

where

Carbohydrate $_{\text {as received }}$ : concentration of the sugars in their polymeric form (glucose in form of glucan, etc.) using an anhydro correction $(0.88$ for pentoses and 0.90 for hexoses).

Klason Lignin $\left(L \frac{g}{100 g T S}\right)=\frac{W_{\text {dried residue }}(g)}{D M_{\text {extracts free }}(g)} \times 100$

Carbohyrate $_{\text {as reiened }}\left(\frac{g}{100 g T S}\right)=$ Suagars $_{\text {extrats free }} \times \frac{100-\text { Total Extractives }}{100}$

Protein content was measured through elemental analysis, using a Nitrogen Factor of 6.25 (Hames et al., 2008). All compositional values were reported in $\mathrm{g} / 100 \mathrm{~g}$ of $\mathrm{DM}$, while 100 minus sum of all measured composition was reported as residue.

\section{Bioethanol potential}

Estimation of ethanol potentials was carried out, following Eq. 6, as described in Thomsen et al. (2014a); it was based on the carbohydrates content in the biomass. Two stoichiometric factors were taken into account; a hydrolysis factor $\left(\beta_{\text {hydrolysis }}\right)$, which describes the hydrolysis of carbohydrate polymers (glucan and xylan) into free sugars, and an ethanol factor $\left(\beta_{\text {fermentation }}\right)$, which describes the mass fraction of sugar monomer converted to ethanol. Using the stoichiometric factors for each of the biomass constituents of the residue and density of ethanol $\left(\rho_{\mathrm{EtOH}}=789 \mathrm{~kg} / \mathrm{m}^{3}\right)$, the bioethanol potentials were calculated.

$$
\begin{gathered}
\text { Ethanol potential }\left(\frac{L}{\text { kgdry matter biomass }}\right)= \\
\text { Glucan }\left(\frac{g}{g d r y \text { matter biomass }}\right) \times \beta_{\text {bydrobsis }} \\
\times \beta_{\text {fermentation }} \div \rho_{E \mathfrak{O H}}\left(\frac{\mathrm{kg}}{\mathrm{m}^{3}}\right) \times 1000
\end{gathered}
$$

The stoichiometric factors used for calculating bioethanol potential are shown in Table 2.

\begin{tabular}{|c|c|c|c|}
\hline \multirow[t]{2}{*}{$\begin{array}{l}\text { Biomass } \\
\text { constituent }\end{array}$} & \multirow[t]{2}{*}{ Formula } & $\begin{array}{l}\text { Conversion } \\
\text { factor in } \\
\text { hydrolysis }\end{array}$ & \multirow{2}{*}{$\begin{array}{c}\begin{array}{c}\text { Conversion } \\
\text { factor in } \\
\text { fermentation }\end{array} \\
\text { g EtOH/g } \\
\text { monomer }\end{array}$} \\
\hline & & $\begin{array}{c}\overline{g \text { monomer/g }} \\
\text { polymer }\end{array}$ & \\
\hline Glucan & $\mathrm{C}_{6} \mathrm{H}_{10} \mathrm{O}_{5}$ & 1.111 & 0.511 \\
\hline Xylan & $\mathrm{C}_{5} \mathrm{H}_{8} \mathrm{O}_{4}$ & 1.136 & 0.511 \\
\hline Arabinan & $\mathrm{C}_{5} \mathrm{H}_{8} \mathrm{O}_{4}$ & 1.136 & 0.511 \\
\hline
\end{tabular}

Table 2: Hydrolysis and ethanol factors for converting different sugars

\section{Biomethane potential}

Biogas production by anaerobic digestion was estimated by the Buswell's formula, Eq. 7 (Symons and Buswell, 1933), which was developed for carbohydrates degradation in anaerobic digestion. This formula can be used to predict theoretical biomethane potential of lignocellulosic biomass, using the chemical composition of degradable carbohydrate fractions, like cellulose, hemicellulose, and lipids while non-degradable lignin can be neglected.

$\mathrm{C}_{n} \mathrm{H}_{a} \mathrm{O}_{b}+\left(n-\frac{a}{4}-\frac{b}{2}\right) \mathrm{H}_{2} \mathrm{O} \rightarrow\left(\frac{n}{2}+\frac{a}{8}-\frac{b}{4}\right) \mathrm{CH}_{4}+\left(\frac{n}{2}-\frac{a}{8}+\frac{b}{4}\right) \mathrm{CO}_{2}$

Biomethane production from protein can be estimated, considering that nitrogen is converted to ammonia, Eq. 8, (Angelidaki and Ellegaard, 2003).

$5 \mathrm{C}_{5} \mathrm{H}_{7} \mathrm{NO}_{2}+6 \mathrm{H}_{2} \mathrm{O} \rightarrow 5 \mathrm{CH}_{4}+5 \mathrm{CO}_{2}+2 \mathrm{NH}_{3}$

In this study, theoretical maximum biomethane potential (mBMP L CH4/kg VS biomass) followed Buswell's formula, Eq. 7 and 8. For lignocellulosic species, near actual biomethane potential (pBMP L CH4/kg VS biomass) followed Thomsen et al. (2014b) model, Eq. 9, where $C, H, L$ and $R$ are weight fractions of cellulose, hemicellulose, lignin and residues, respectively. The model displays positive coefficients for $C, H$, and $R$, while lignin, $L$, has negative coefficient indicating its negative effect on biomethane yield.

$$
p B M P=378 C+354 H-194 L+313 R
$$

\section{RESULTS AND DISCUSSION}

Compositional analysis of biomass from different sources showed a wide diversity in the structural components, Table 3. Date palm fruit stalks and rachis showed a glucan content of $41.2 \pm 1.0$ and $35.6 \pm 3.9 \mathrm{~g} / 100 \mathrm{~g} \mathrm{DM}$, being this values the highest among the samples of the lignocellulosic biomass analyzed. All date palm fractions had a lignin content higher than $25 \mathrm{~g} / 100 \mathrm{~g} \mathrm{DM}$, while for the rest of lignocellulosics the content ranged between 13.5 and $16.8 \mathrm{~g} / 100 \mathrm{~g}$ DM. This pattern indicated that the 
Ashraf, et al.: Estimation of bioenergy potential for local biomass in the United Arab Emirates

Table 3: Composition analysis of UAE local biomass (g/100g DM)

\begin{tabular}{|c|c|c|c|c|c|c|c|c|c|}
\hline Class & Biomass & Glucan & Xylan & Arabinan & $\begin{array}{l}\text { Klason } \\
\text { Lignin }\end{array}$ & $\begin{array}{c}\text { Structural } \\
\text { Ash }\end{array}$ & Extractives & Protien & Residue \\
\hline \multirow[t]{9}{*}{ Lignocellulose } & Date palm leaflets & $20.6 \pm 0.2$ & $10.5 \pm 0.2$ & $0.9 \pm 0.5$ & $30.3 \pm 0.7$ & $9.8 \pm 0$ & $29.7 \pm 1$ & $6 \pm 0^{a}$ & $-1.8 \pm 0$ \\
\hline & Date palm trunks & $28.1 \pm 2.6$ & $17.7 \pm 0.4$ & $0 \pm 0$ & $26.5 \pm 1$ & $6.1 \pm 0.9$ & $16.5 \pm 1$ & n.d. & $5.1 \pm 0$ \\
\hline & Date palm fruit stalk & $41.2 \pm 1$ & $21.5 \pm 0.5$ & $0 \pm 0$ & $28.3 \pm 1$ & $3.5 \pm 0.6$ & $9.3 \pm 1$ & $4 \pm 0$ & $-3.8 \pm 0$ \\
\hline & Date palm rachis & $35.6 \pm 3.9$ & $20.1 \pm 1$ & $1.9 \pm 0.1$ & $25 \pm 0.2$ & $4.7 \pm 0.2$ & $17 \pm 3.1$ & $6 \pm 0$ & $-4.3 \pm 0$ \\
\hline & Moringa peregina & $32.8 \pm 0.1$ & $11.8 \pm 0.1$ & $1.5 \pm 0$ & $16.8 \pm 0.2$ & $4.7 \pm 0$ & $24.1 \pm 0.7$ & n.d. & $8.3 \pm 0$ \\
\hline & Bermuda Grass & $19.4 \pm 1.6$ & $12.2 \pm 0.7$ & $3.4 \pm 0.2$ & $15.5 \pm 0.7$ & $13.8 \pm 0.4$ & $18.1 \pm 0.4$ & n.d. & $17.6 \pm 0$ \\
\hline & Jasmine Hedges & $21.2 \pm 1.9$ & $10.6 \pm 0.6$ & $2.5 \pm 0.2$ & $14.8 \pm 0.2$ & $11.2 \pm 0.2$ & $18.6 \pm 0.1$ & n.d. & $21.2 \pm 0$ \\
\hline & A. Marina Stems & $23.8 \pm 0$ & $17.9 \pm 0$ & $10.5 \pm 0$ & $13.5 \pm 0$ & $2.1 \pm 0$ & $34 \pm 0$ & n.d. & $-1.8 \pm 0$ \\
\hline & A. Marina Leaves & $12.6 \pm 0.7$ & $9.1 \pm 0.5$ & $7.3 \pm 0.2$ & $15.6 \pm 2.1$ & $5.2 \pm 0$ & $47.4 \pm 0$ & n.d. & $2.9 \pm 0$ \\
\hline \multirow[t]{3}{*}{ Seagrasses } & H. Uninervis & $11.3 \pm 0.2$ & $1.3 \pm 0.3$ & $0.5 \pm 0.3$ & $17.5 \pm 4.1$ & $49.4 \pm 4.4$ & $19.6 \pm 1.1$ & $11.8 \pm 0.2$ & $0.5 \pm 0$ \\
\hline & H. Stipulacea & $17.4 \pm 0.4$ & $2.3 \pm 0.2$ & $2.9 \pm 0.1$ & $7.6 \pm 0.7$ & $18.7 \pm 2.6$ & $22.8 \pm 2.3$ & $9.8 \pm 0.7$ & $28.4 \pm 0$ \\
\hline & H. Ovalis & $11.4 \pm 4.1$ & $3.5 \pm 1.3$ & $2.8 \pm 1$ & $4.5 \pm 2.3$ & $33.8 \pm 1$ & $33.4 \pm 1.4$ & $12.9 \pm 0.9$ & $10.5 \pm 0$ \\
\hline \multirow[t]{3}{*}{ Halophytes } & Juice of $S$. sinus-persica & $6.5 \pm 1$ & $2.9 \pm 0.8$ & $0.3 \pm 0.2$ & - & $58 \pm 0.2$ & - & $6.6 \pm 0$ & $32.4 \pm 0$ \\
\hline & Pulp of S. sinus-persica & $15.6 \pm 0.5$ & $10.7 \pm 0.6$ & $11.1 \pm 0.4$ & $14.6 \pm 1.9$ & $19.8 \pm 0.8$ & - & $13 \pm 0$ & $28.2 \pm 0$ \\
\hline & S. bigelovii & $9.1 \pm 1.5$ & $7.7 \pm 0.4$ & $5.5 \pm 2.1$ & $6.8 \pm 1.4$ & $6.8 \pm 0.1$ & $53.7 \pm 3.6$ & $13.3 \pm 0^{b}$ & $10.4 \pm 0$ \\
\hline \multirow[t]{3}{*}{ Washed halophytes } & Juice of $S$. sinus-persica & $7.6 \pm 0.4$ & $3.3 \pm 0.3$ & $0.1 \pm 0$ & - & $61.1 \pm 3.6$ & - & $7.7 \pm 0$ & $27.9 \pm 0$ \\
\hline & Pulp of S. sinus-persica & $16.3 \pm 1.5$ & $11.6 \pm 1$ & $11 \pm 1.2$ & $14.9 \pm 4$ & $19.7 \pm 0.3$ & - & $13 \pm 0$ & $26.5 \pm 0$ \\
\hline & S. bigelovii & $25.8 \pm 2$ & $21.6 \pm 1.5$ & $5.7 \pm 1.8$ & $7.7 \pm 0.1$ & $5.5 \pm 0.5$ & $18.3 \pm 1.2$ & $13.3 \pm 0^{b}$ & $15.4 \pm 0$ \\
\hline \multirow[t]{3}{*}{ Macroalgea } & Ulva Sp. & $7.3 \pm 0.2$ & $3.1 \pm 0.1$ & $7.7 \pm 0.1$ & $13.7 \pm 0.6$ & $7.8 \pm 0.4$ & $58.1 \pm 1.4$ & $17 \pm 0.4$ & $2.3 \pm 0$ \\
\hline & P. boergesenii & $8.1 \pm 0$ & $3.7 \pm 0$ & $0.5 \pm 0$ & $13.1 \pm 0.5$ & $39.2 \pm 1.9$ & $26 \pm 1.2$ & $5.9 \pm 0.4$ & $9.5 \pm 0$ \\
\hline & C. sinuosa & $9.5 \pm 0.1$ & $3.3 \pm 0.1$ & $0.3 \pm 0$ & $16.9 \pm 1.9$ & $32.3 \pm 1.8$ & $25 \pm 1.1$ & $8.2 \pm 0.4$ & $12.8 \pm 0$ \\
\hline \multirow[t]{5}{*}{ Muncipal and animal waste } & Dry OFMSW & $36.3 \pm 3.3$ & $1.4 \pm 0.2$ & $0.2 \pm 0.1$ & $2.5 \pm 0.6$ & $4 \pm 0$ & $31.9 \pm 0.8$ & $2 \pm 0$ & $23.7 \pm 0$ \\
\hline & Camel dung & $18.7 \pm 0.1$ & $11.4 \pm 0.3$ & n.d. & $26.8 \pm 0.9$ & $13.8 \pm 2.9$ & $13.7 \pm 0.5$ & n.d. & $15.8 \pm 0$ \\
\hline & Sheep dung & $15.2 \pm 0.7$ & $5.9 \pm 0.6$ & n.d. & $13.9 \pm 0.8$ & $17.6 \pm 1.2$ & $17.6 \pm 0.3$ & n.d. & $30 \pm 0$ \\
\hline & Goat dung & $16.5 \pm 1.1$ & $4.2 \pm 0.9$ & n.d. & $14.6 \pm 1.2$ & $22.1 \pm 2.3$ & $23 \pm 0.8$ & n.d. & $19.7 \pm 0$ \\
\hline & Cattle dung & $15.9 \pm 2.3$ & $6.9 \pm 0.9$ & n.d. & $19.2 \pm 3.5$ & $10.9 \pm 0.8$ & $15 \pm 0.5$ & n.d. & $32.3 \pm 0$ \\
\hline
\end{tabular}

a(Lu et al., 2010), b(Arhab et al., 2006)

date palm fraction will be more recalcitrant to biological conversions than the other lignocellulosics. Moringa pereinga seemd to be more suitable for biological conversions, as it revealed a high glucan content of $32.8 \pm 0.1 \mathrm{~g} / 100 \mathrm{~g} \mathrm{DM}$, and relatively low lignin content $(16.8 \pm 0.2 \mathrm{~g} / 100 \mathrm{~g} \mathrm{DM})$. A. Marina stems and leaves had the largest fraction of water and ethanol extractives among lignocellulosics. H. stipulacea contained the highest glucan content $(17.4 \pm 0.4 \mathrm{~g} / 100 \mathrm{~g}$ $\mathrm{DM}$ ) among raw halophytes. Juice from $S$. sinus-persica was found to have a high ash content relatively to the pulp fraction, which showed that the surface salt deposits go to the juice fraction during pressing. Extractives in S. bigelovii decreased from $53.7 \pm 3.6 \mathrm{~g} / 100 \mathrm{~g}$ DM to $18.3 \pm 1.2 \mathrm{~g} / 100 \mathrm{~g}$ DM, by washing, meaning that most of the extractives were surface impurities that could be easily removed by water wash. Washing S. sinus-persica had little impact. As a result washed S. bigelovii revealed the highest glucan and xylan content among halophytes. From municipal and animal wastes, mOFMSW displayed the highest glucan content (36.3 $\pm 1 \mathrm{~g} / 100 \mathrm{~g} \mathrm{DM})$, while camel dung had high glucan and xylan content $(30 \mathrm{~g} / 100 \mathrm{~g} \mathrm{DM})$ among manures.

Total bioethanol potential of different biomass types showed a wide spectrum, varying from $55 \mathrm{~kg}$ ethanol/t dry biomass (juice of unwashed S. sinus-persica) to $359 \mathrm{~kg}$ ethanol/t dry biomass (date palm fruit stalk). Date palm rachis, washed $S$. bigelovii, and mangroves (A. Marina) stems remained among the second highest level of bioethanol potential, which was between 300 and $350 \mathrm{~kg}$ ethanol/t dry biomass. There were ten biomass types and fractions (date palm leaflets and trunk, Moringa peregrina, pulp of unwashed and washed S. sinus-persica, Bermuda grass, Jasmine hedges, mangroves leaves, dry OFMSW, and camel dung) with a bioethanol potential (within 150-300 kg ethanol/t dry biomass). The bioethanol potential below $150 \mathrm{~kg}$ ethanol/t dry biomass include juice of unwashed and washed S. sinus-persica, unwashed S. bigelovii, H. Ovalis, H. Uninervis, H. Stipulacea, sheep dung, goat dung, and cattle dung. Considering the bioethanol potential derived from glucose, date palm fruit stalk was the best candidate biomass, offering $234 \mathrm{~kg}$ ethanol/t dry biomass, while juice from $S$. sinus-persica was the worst, offering $37 \mathrm{~kg}$ ethanol $/ \mathrm{t}$ dry biomass. The biomass and fractions that were capable of providing 150-200 kg ethanol/t dry biomass were date palm trunk and rachis, dry OFMSW, Moringa peregrina, and washed S. bigelovii. A quarter of the biomass and fractions investigated had bioethanol potential within $100-150 \mathrm{~kg}$ ethanol/t dry biomass (mangroves stems, date palm leaflets, Bermuda grass, Jasmine hedges, H. Stipulacea, camel dung). Bioethanol potential of most biomass and fractions was less 
than $100 \mathrm{~kg}$ ethanol/t dry biomass (Pulp and Juice from S. sinus-persica (unwashed and washed), mangrove leaves, H. Uninervis, H. Ovalis, Ulva Sp., P. boergesenii, C. sinuosa, and dung from sheep, goat and cattle). Contributions of xylose and arabinose to bioethanol potential of most biomass and fractions were less than $50 \%$, except pulp of unwashed and washed S. sinus-persica, unwashed and washed S. bigelovii, Ulva Sp., and mangroves stems and leaves.

The assessed biomass includes lignocellulose (date palm residues, Moringa peregrina, Bermuda grass, Jasmine hedges and mangroves), halophytes ( $S$. sinus-persica, S. bigelovii, H. Uninervis, H. Stipulacea, and H. Ovalis,), macroalgae (Ulva Sp., P. boergesenii, and C. sinuosa), and municipal and animal waste (OFMSW, and dung from sheep, goat, cattle and camel) biomass with a wide spectrum of carbohydrates content, which, consequently, generates a wide spectrum of bioethanol potential. Following a general perspective, the order of bioethanol potential is the following: lignocellulose (trees) $>$ washed halophytes (pulp) $>$ lignocellulose (grass and hedges) $>$ municipal and animal waste $>$ unwashed halophytes $>$ macroalgae (Fig. 1). Rachis or stems tends to have more bioethanol potential than leaves, as for date palm and Mangroves. Pulp of halophytes tends to have more bioethanol potential than juice, regarding $S$. sinus-persica.

The UAE has the largest number of date palms for any single country in the world, producing around 2 million tons of residues annually. The abundance of biomass and the highest bioethanol potential indicate that date palm is a good lignocellulosic biomass for bioethanol production. S. bigolovii is currently grown in the Middle East, for fodder for lamb, sheep and goats, which have the ability to tolerate high-sodium diet. Cybulska et al. (2013) reported that the washed feedstock after hydrothermal pretreatment, produced highly digestible (up to $92 \%$ glucan-to-glucose conversion) and fermentable (up to $100 \%$ glucose-to-ethanol conversion) fiber fractions, which is indicating that $S$. bigolovii might also be a promising halophilic biomass for bioethanol production. However, fresh water wash is required prior to any processing to remove the salt deposits (Cybulska et al., 2014), limiting its application prospective. The macroalgae, considered as a third generation biomass for bioethanol production (Singh et al., 2011), has high productivity per unit area per year, and there is no competition with arable lands. The lower lignin content of macroalgae makes effective pretreatment possible at relatively milder conditions of temperature and have higher yields from the enzymatic hydrolysis of macroalgae cellulose (John et al., 2011). These advantages suggest that macroalgae could also be another promising biomass for bioethanol production in the UAE, despite of the low bioethanol potential. Besides, OFMSW has a comparable high bioethanol potential with lignocellulosic biomass. Moreover, the biorefinery of OFMSW to produce biofuels, not only minimizes the risk to human health, but reduces environmental burden (Khalid et al., 2011). Thus, it is thought to be one of the most promising and sustainable way of valorization of MSW (Shi et al., 2009). Management practices for dung, generated by livestock, primarily consists of stockpiling (dry pad and lagoon) and application to soils, either directly and/or following composting. However, issues associated with microbial/nutrient runoff and contamination of surface and groundwater, high nitrogen and phosphorous soil loads, odour and generation of GHG, such as methane and nitrous oxide, diminish their environmental, health and economic appeal (Vancov et al., 2015). However, manure is one of the good sources of biogas production by codigestion with other biomass (Angelidaki and Ellegaard, 2003).

Theoretical biomethane potential mBMP for lignocellulosic (Fig. 2) ranged from 72 to $288 \mathrm{~L} \mathrm{CH}_{4} / \mathrm{kg}$ VS biomass. Among lignocellulosics, date palm fruit stalk and rachis,

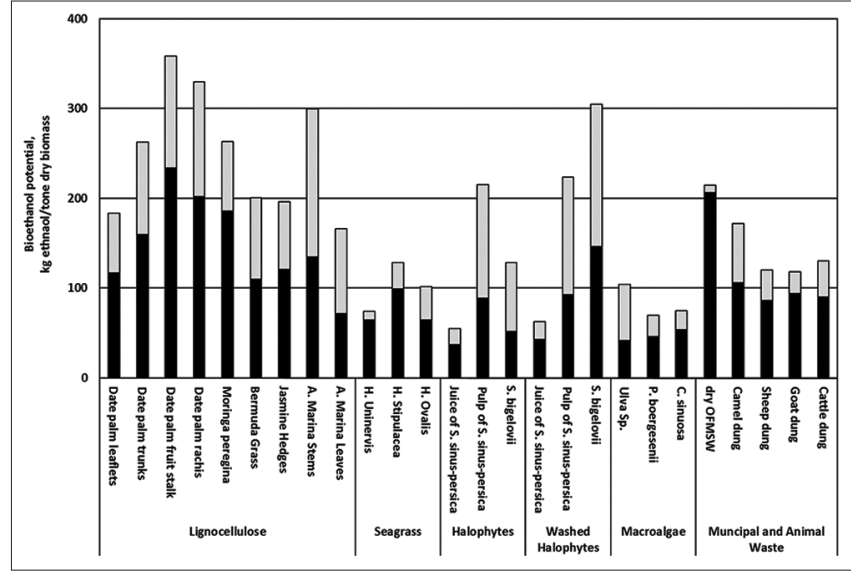

Fig 1. Bioethanol potential of different biomass sources in the UAE. The black bars represent ethanol converted from glucose ( $C_{6}$ sugars), the grey bars represent ethanol converted from xylose and arabinose $\left(C_{5}\right.$ sugars).

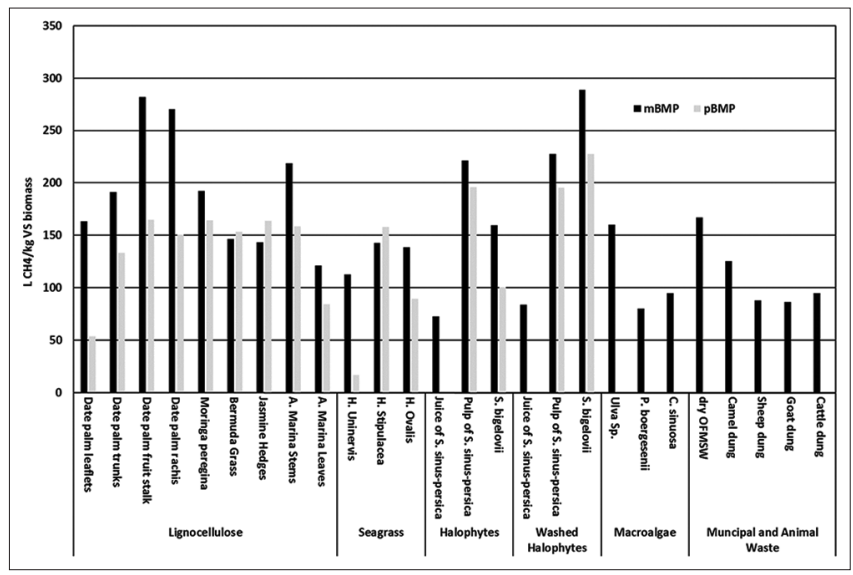

Fig 2. Estimate of biomethane potential by the Buswells formula (mBMP) and the regression model (pBMP). 
and A. marina stems showed the high mBMP $(>200 \mathrm{~L}$ $\mathrm{CH}_{4} / \mathrm{kg}$ VS biomass), mostly due to high glucan and xylan contents. Although date palm fruit stalk, rachis, and A. marina stems revealed a high level of mBMP, taking the negative effect of lignin into account, using pBMP, is expected a biomethane potential of 150 to $165 \mathrm{~L}$ $\mathrm{CH}_{4} / \mathrm{kg}$ VS. Although Bermuda grass and Jasmine hedges had lower glucan and xylan content but had comparable biomethane potential pBMP of $150-165 \mathrm{~L} \mathrm{CH}_{4} / \mathrm{kg}$ VS. Date palm and $A$. marina leaves showed low $\mathrm{pBMP}(<100 \mathrm{~L}$ $\mathrm{CH}_{4} / \mathrm{kg}$ VS biomass), as compared to other lignocellulosic fractions.

Among halophytes pulp of raw and washed $S$. sinusperisca had the highest mBMP (>220 L CH $/ 4$ kg VS biomass), while juice fraction of $S$. sinus-perisca revealed low mBMP, as it consisted of more than $58 \%$ ash. Water washing increased the biomethane potential of $S$. bigelovii, considering $\mathrm{mBMP}$ and $\mathrm{pBMP}\left(>200 \mathrm{~L} \mathrm{CH}_{4} / \mathrm{kg}\right.$ VS biomass), which makes it a top contender for biomethane production from the UAE local biomass. Rest of halophytes, H. Uninervis, H. Stipulacea, and H. Ovalis, showed an mBMP in the range of 112 to $142 \mathrm{~L} \mathrm{CH}_{4} / \mathrm{kg}$ VS biomass. Macroalgae fractions of $P$. boergesenii and C. sinuosa revealed an mBMP lesser than $100 \mathrm{~L} \mathrm{CH}_{4} / \mathrm{kg}$ VS biomass, due to lower carbohydrates and high ash and extractives. Ulva Sp. displayed a relatively high mBMP (160 L CH$/ / \mathrm{kg}$ VS biomass) among macroalgae, due to the high degradable carbohydrates $(18.1 \mathrm{~g} / 100 \mathrm{~g}$ DM). Among waste, biomass OFMSW had the highest theoretical biomethane potential mBMP, while camel manure showed the highest among animal manure.

Biomethane from wastes is an environmentally friendly method of waste management. Biomethane from camel dung seems to have a promising scope, due to large population of camels in the UAE (about 392,667 heads, counted in 2013 (National Bureau of Statistics, 2013b), and high biomethane potential among other animal manure waste. Bermuda grass and Jasmine hedges generate a regular stream of waste due to trimming and maintenance of landscape and gardens. Per capita municipal waste in the UAE is one of the highest in the world (National Bureau of Statistics, 2013a, 2011). Biomethane potential mBMP of these biomass is $140-165 \mathrm{~L} \mathrm{CH}_{4} / \mathrm{kg} \mathrm{VS}$, which shows a capacity for being an alternative of biomethane production rather than waste management by landfill. Animal manure from farms can be mixed with these wastes to further improve the methane potential (Angelidaki and Ellegaard, 2003). This will not only improve the economic cost of waste management, but also be beneficial by mitigating the harmful effect of anthropogenic methane production for landfills.

\section{CONCLUSIONS}

Biomass analyzed showed promising results for bioenergy production in UAE. Lignocellulosic biomass was the most potential candidate of bioethanol production followed by green biomass and macroalgae, while wastes provide the least bioethanol potential. For biomethane production washed $S$. bigelovii was the top contender followed by lignocellulosics, OFMSW and camel manure. Significant differences of bioenergy potential were observed between fractions of the same biomass type.

\section{ACKNOWLEDGEMENT}

This study was support by MIT\&MI Flagship project (Biorefinery: Integrated Sustainable Processes for Biomass Conversion to Biomaterials, Biofuels and Fertilizers) (http://web.mit.edu/mit-mi-cp/research/flagship.html).

\section{AUTHOR CONTRIBUTIONS}

The work has been completed under the supervision of M. H. T. and J. E. S.; M. T. A. and C. F. are the main contributors in writing with assistances from all the coauthors. Following is a list for data contributions: date plam by C. F., Bermuda grass and Jasmine hedges by M. T. A., Salicornia bigelovii by T. C., Salicornia sinus-persica by A. A., animal manure by A. S., Seagrass and macro algae by R. F. and G. P. B., Mangroves by I. C., Moringa peregrina by T. B., and OFMSW by S. H.

\section{REFERENCES}

Angelidaki, I. and L. Ellegaard. 2003. Codigestion of manure and organic wastes in centralized biogas plants. Appl. Biochem. Biotechnol. 109: 95-105.

Arhab, R., D. Macheboeuf, M. Doreau and H. Bousseboua. 2006. Nutritive value of date palm leaves and Aristida pungens estimated by chemical, in vitro and in situ methods. Trop. Subtrop. Agroecosystems. 6: 167-175.

Blanchard, R., P. J. O'Farrell and D. M. Richardson. 2015. Anticipating potential biodiversity conflicts for future biofuel crops in South Africa: Incorporating spatial filters with species distribution models. GCB Bioenergy. 7: 273-287.

Butt, S., I. Hartmann and V. Lenz. 2013. Bioenergy potential and consumption in Pakistan. Biomass Bioenergy. 58: 379-389.

CEU. 2007. Presidency Conclusions, Council of the European Union, Brussels.

Cybulska, I., T. Chaturvedi, G. P. Brudecki, Z. Kádár, A. S. Meyer, R. M. Baldwin and M. H. Thomsen. 2014. Chemical characterization and hydrothermal pretreatment of Salicornia bigelovii straw for enhanced enzymatic hydrolysis and bioethanol potential. Bioresour. Technol. 153: 165-172.

DuPont. 2015a. Cellulosic Ethanol Plant - Nevada, lowa | DuPont USA, [WWW Document]. Avauilable from: http://www.dupont. 
com/products-and-services/industrial-biotechnology/advancedbiofuels/cellulosic-ethanol/nevada-iowa-cellulosic-ethanol-plant. html. [Last accessed on 2015 Mar 11].

DuPont. 2015b. DuPont, Quad County Corn Processors Sign Enzyme Supply Contract | Biomassmagazine.com [WWW Document]. Biomass Mag. Avalable from: http://www.biomassmagazine. com/articles/12476/dupont-quad-county-corn-processors-signenzyme-supply-contract. [Last accessed on 2015 Mar 11].

EISA. 2007. Energy Independence and Security Act of 2007. US Congress.

El-Juhany, L. 2010. Degradation of date palm trees and date production in Arab countries: Causes and potential rehabilitation. Aust. J. Basic Appl. Sci. 4: 3998-4010.

Emirates News Agency. 2009. Abu Dhabi Commits to 7 Percent Renewable Energy Target by 2020 [WWW Document]. Available from: http://www.wam.ae/en/news/emirates/1395228272413. html. [Last accessed on 2014 Sep 11].

Hames, B., C. Scarlata and A. Sluiter. 2008. Determination of Protein Content in Biomass. National Renewable Energy Laboratory.

Hiloidhari, M., D. Das and D. C. Baruah. 2014. Bioenergy potential from crop residue biomass in India. Renew. Sustain. Energy Rev. 32: 504-512.

ICBA, 2011. Evaluation of Salicornia Bigelovii Under Different Salinity Levels, Independent Community Bankers of America, Dubai.

IEA. 2014. Key World Energy Statistics, International Energy Agency; OECD, Paris.

IEA, 2013. World Energy Outlook, Organisation for Economic CoOperation and Development, Paris.

IEA Bioenergy. 2009. Bioenergy - A Sustainable and Reliable Energy Source, IEA Bioenergy, Paris.

Inbicon. 2015. Kalundborg Demonstration Plant [WWW Document]. Available from: http://www.inbicon.com/en/global-solutions/ danish-projects. [Last accessed on 2015 Mar 11].

IPCC. 2014. Climate Change 2014: Mitigation of Climate Change. Contribution of Working Group III to the Fifth Assessment Report, Cambridge University Press, Berlin.

Ji, L. Q. 2015. An assessment of agricultural residue resources for liquid biofuel production in China. Renew. Sustain. Energy Rev. 44: 561-575.

John, R. P., G. S. Anisha, K. M. Nampoothiri and A. Pandey. 2011. Micro and macroalgal biomass: A renewable source for bioethanol. Bioresour. Technol. 102: 186-193.

Khalid, A., M. Arshad, M. Anjum, T. Mahmood and L. Dawson. 2011. The anaerobic digestion of solid organic waste. Waste Manag. 31: 1737-1744.

Lu, D., M. Zhang, S. Wang, J. Cai, X. Zhou and C. Zhu. 2010. Nutritional characterization and changes in quality of Salicornia bigelovii Torr. during storage. LWT - Food Sci. Technol. 43: 519-524.

Mallaki, M. and R. Fatehi. 2014. Design of a biomass power plant for burning date palm waste to cogenerate electricity and distilled water. Renew. Energy. 63: 286-291.

MEC. 2015. Maabjerg Energy Center [WWW Document]. Available from: http://www.maabjergenergycenter.dk/fakta-om-mec/inputoutput/. [Last accessed on 2015 Mar 11].

National Bureau of Statistics. 2013a. Waste Statistics 2013, National Bureau of Statistics, Abu Dhabi.

National Bureau of Statistics. 2013b. Livestock Statistics 2013, National Bureau of Statistics, Abu Dhabi.

National Bureau of Statistics. 2011. Population Estimates 2006-210,
National Bureau of Statistics, Abu Dhabi.

Nwobi, A., I. Cybulska, W. Tesfai, Y. Shatilla, J. Rodríguez and M. H. Thomsen. 2014. Simultaneous saccharification and fermentation of solid household waste following mild pretreatment using a mix of hydrolytic enzymes in combination with Saccharomyces cerevisiae. Appl. Microbiol. Biotechnol. 2018: 1-10.

Qiu, H., L. Sun, J. Huang and S. Rozelle. 2012. Liquid biofuels in China: Current status, government policies, and future opportunities and challenges. Renew. Sustain. Energy Rev. 16: 3095-3104.

Rozema, J. and T. Flowers. 2008. Crops for a salinized world. Science. 322(80):1478-1480.

Searle, S. and C. Malins. 2015. A reassessment of global bioenergy potential in 2050. GCB Bioenergy. 7: 328-336.

Shahin, S., M. Abdul and M. Salem. 2014. Four reasons will convince the landscape decision makers to go for indigenous plants in the United Arab Emirates ( UAE). Int. J. Recent Dev. Eng. Technol. 3: 1-8.

Shi, A. Z., L. P. Koh and H. T. W. Tan. 2009. The biofuel potential of municipal solid waste. GCB Bioenergy. 1: 317-320.

Shriadah, M. M. A. 1999. Heavy metals in mangrove sediments of the united arab emirates shoreline (arabian gulf). Water Air Soil Pollut. 116: 523-534.

Singh, A., P. S. Nigam and J. D. Murphy. 2011. Renewable fuels from algae: An answer to debatable land based fuels. Bioresour. Technol. 102: 10-16.

Sluiter, A., B. Hames, D. Hayman, C. Payne, R. Ruiz, C. Scarlata, J. Sluiter, D. Templeton and J. Wolfe. 2008a. Determination of total solids in biomass and total dissolved solids in liquid process samples laboratory analytical procedure (LAP). National Renewable Energy Laboratory.

Sluiter, A., B. Hames, R. Ruiz, C. Scarlata, J. Sluiter and D. Templeton. 2008b. Determination of Ash in Biomass Laboratory Analytical Procedure (LAP). National Renewable Energy Laboratory.

Sluiter, A., B. Hames, R. Ruiz, C. Scarlata, J. Sluiter, D. Templeton and D. Crocker. 2011. Determination of Structural Carbohydrates and Lignin in Biomass Laboratory Analytical Procedure (LAP). National Renewable Energy Laboratory.

Sluiter, A., R. Ruiz, C. Scarlata, J. Sluiter and D. Templeton. 2008c. Determination of Extractives in Biomass Laboratory Analytical Procedure (LAP). National Renewable Energy Laboratory.

Symons, G. E. and A. M. Buswell. 1933. The methane fermentation of carbohydrates. J. Am. Chem. Soc. 55: 2028-2036.

Tan, Z., S. Liu, N. Bliss and L. L. Tieszen. 2012. Current and potential sustainable corn stover feedstock for biofuel production in the United States. Biomass Bioenergy. 47: 372-386.

Thomsen, S. T., Z. Kádár and J. E. Schmidt. 2014a. Compositional analysis and projected biofuel potentials from common West African agricultural residues. Biomass Bioenergy. 63: 210-217.

Thomsen, S. T., H. Spliid and H. Østergård. 2014b. Statistical prediction of biomethane potentials based on the composition of lignocellulosic biomass. Bioresour. Technol. 154: 80-86.

US DOE. 2015. Largest Cellulosic Ethanol Plant in the World Opens October 30 | Department of Energy [WWW Document]. Off. Energy Effic. Renewable Energy. Available from: http://www. energy.gov/eere/bioenergy/articles/largest-cellulosic-ethanolplant-world-opens-october-30. [Last accessed on 2015 Mar 11].

Vancov, T., R. C. S. Schneider, J. Palmer, S. McIntosh and R. Stuetz. 2015. Potential use of feedlot cattle manure for bioethanol production. Bioresour. Technol. 183: 120-128. 